\section{9}

High Content Imaging 2019

February 12, 2019

Nottingham, UK

www.rms.org.uk/discover-engage/eventcalendar

an-introduction-to-high-contentimaging.html

Cell Symposium: Single Cells:

Technology to Biology

February, 24-26, 2019

Singapore

www.cell-symposia.com/single-cells/default.asp

Biophysical Society 63rd Annual

\section{Meeting}

March 2-6, 2019

Baltimore, MD

www.biophysics.org/Meetings/AnnualMeeting/

FutureAnnualMeetings/tabid/495/Default.aspx

PITTCON Conference \& Expo 2019

March 17-21, 2019

Philadelphia, PA

https://pittcon.org

ACS Spring Meeting: Chemistry for New

\section{Frontiers}

March 31-April 4, 2019

Orlando, FL

www.acs.org/content/acs/en/meetings/

national-meeting/abstract-submission.

html?sc=meetings_1800815_mtg_\%200R19_od

FOM2019: Focus on Microscopy 2019

April 14-17, 2019

London, UK

www microbeamanalysis eu/events/

event/57-fom2019-focus-on-microscopy-2019

MRS Spring Meeting \& Exhibit

April 22-26, 2019

Phoenix, AZ

www.mrs.org/spring2019

Microscopy \& Microanalysis 2019

August 4-8, 2019

Portland, OR

www.microscopy.org

\section{0}

Microscopy \& Microanalysis 2020

August 2-6, 2020

Milwaukee, WI

www.microscopy.org

\section{1}

Microscopy \& Microanalysis 2021

August 1-5, 2021

Pittsburgh, PA

www.microscopy.org

2022

Microscopy \& Microanalysis 2022

July 31-August 4, 2022

Portland, OR

www.microscopy.org

\section{3}

Microscopy \& Microanalysis 2023

July 24-28, 2023

Minneapolis, MN

www.microscopy.org

More Meetings and Courses

Check the complete calendar near the back of this magazine.

\title{
Did Beetles Pollinate Ancient Plants?
}

\author{
Stephen W. Carmichael \\ Mayo Clinic, Rochester, MN 55905 \\ carmichael.stephen@mayo.edu
}

Back when dinosaurs roamed the Earth, cycads dominated the plant life. Cycads are gymnosperms that are characterized by "naked" seeds, often in cones. Modern examples are conifers and Ginkgo, which are pollinated by the wind. Later in geologic time flowering plants (angiosperms) dominated; they are mostly pollinated by flying insects such as bees and butterflies. Interestingly cycads are pollinated typically by beetles. Today there are more than 380,000 named species of beetles constituting almost $25 \%$ of known life forms on our planet. A relatively small family of beetles, the Broganiidae, is characterized by large mouthparts that are specialized for pollination. Today broganiids are found in nature only in the Southern hemisphere, leading to the suggestion that they evolved before the eventual breakup of the ancient supercontinent of Gondwana about 167 million years ago to form our continents.

Although it is well documented that cycads were diverse and abundant during the mid-Mesozoic era when Gondwana began splitting, little is known about their distribution and pollination before the rise of angiosperms. The recent discovery of a beetle in a piece of amber from Myanmar (Figure 1), by Chenyang Cai and an international team of scientists [1], may fill in some of the gap in this knowledge.

The fossil record for these small ( $2 \mathrm{~mm}$ long) beetles and cycad pollen grains ( $20 \mu \mathrm{m}$ long) is very sparse because of the rarity of preserving them in a manner that reveals morphologic detail. Cai et al. solved this problem by examining extant boganiid beetles. Using scanning electron microscopy, they demonstrated the presence of small cavities in mouth parts (specifically the mandible) of these beetles. The cavities contained bristles that facilitate the transfer of pollen between plants (Figure 2).

The piece of amber examined by Cai et al. was determined to be about 99 million years old. The mouth parts of the beetle were examined by light microscopy and were found to have characteristics of boganiid beetles. These and other structures led Cai et al. to name this beetle as a new species, Cretoparacucujus cycadophilus. Cretoparacucujus was compared to modern beetles that pollinate gymnosperms in the Southern hemisphere.

Remarkably, several pollen grains are present in the same piece of amber. Although it was not possible to definitively identify these grains as coming from cycads, they may have. If this is the case, Cai et al. have demonstrated for the first time that insect pollination occurred much earlier in the fossil record than previously demonstrated. Since previous findings have shown that both beetles and cycads coexisted at least

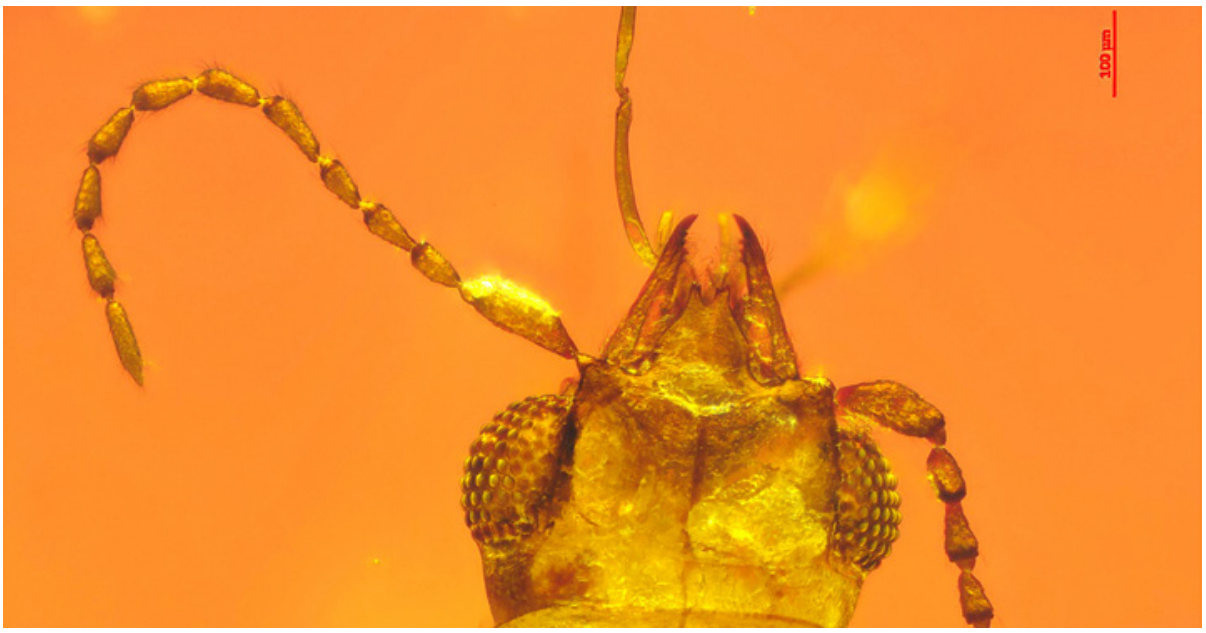

Figure 1: Light microscope image of dorsal view of Cretoparacucujus cycadophilus in amber showing mandibular cavities. Image width $=2 \mathrm{~mm}$. 


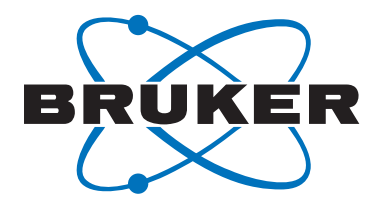

\section{Proven}

\section{Electron Microscopy} Solutions

\section{QUANTAX EDS}

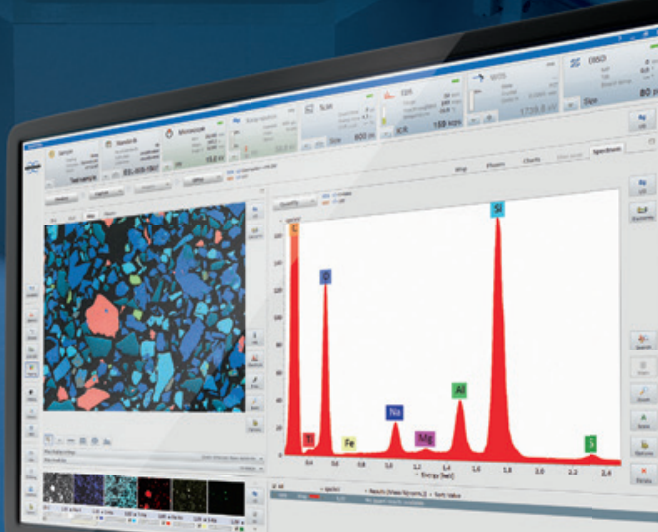

- Featuring XFlash ${ }^{\circledR} 6$ - worldwide leading SDD technology for SEM and TEM

- Delivering the fastest, most accurate EDS results

- Easiest-to-use EDS, available in configurations for every budget

- Integration of EDS, WDS, EBSD and Micro-XRF on SEM under a single user interface

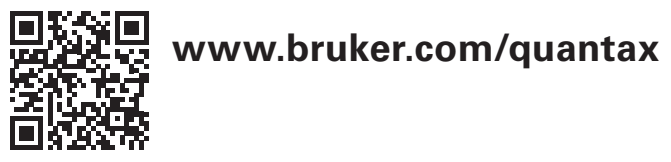

Innovation with Integrity 


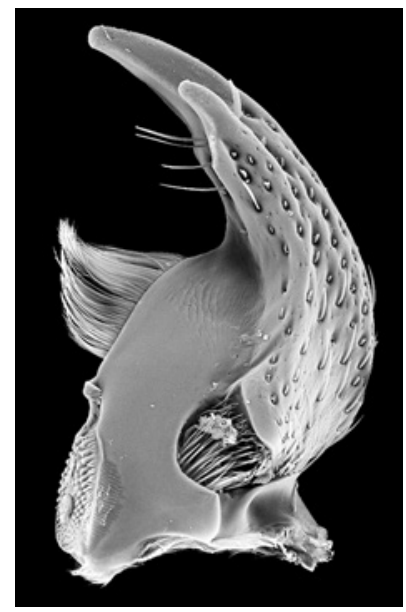

Figure 2: Scanning electron microscope image of right mandible of the extant Paracucujus rostratus. Image width $=700 \mu \mathrm{m}$.

250 million years ago, they may have been interacting even back then. This exciting new study suggests insect pollination occurred much earlier that previously thought! [2]

\section{References}

[1] C Cai et al., Current Biology 28 (2018) 2806-12.

[2] The author gratefully acknowledges Dr. Chenyang Cai for reviewing this article.

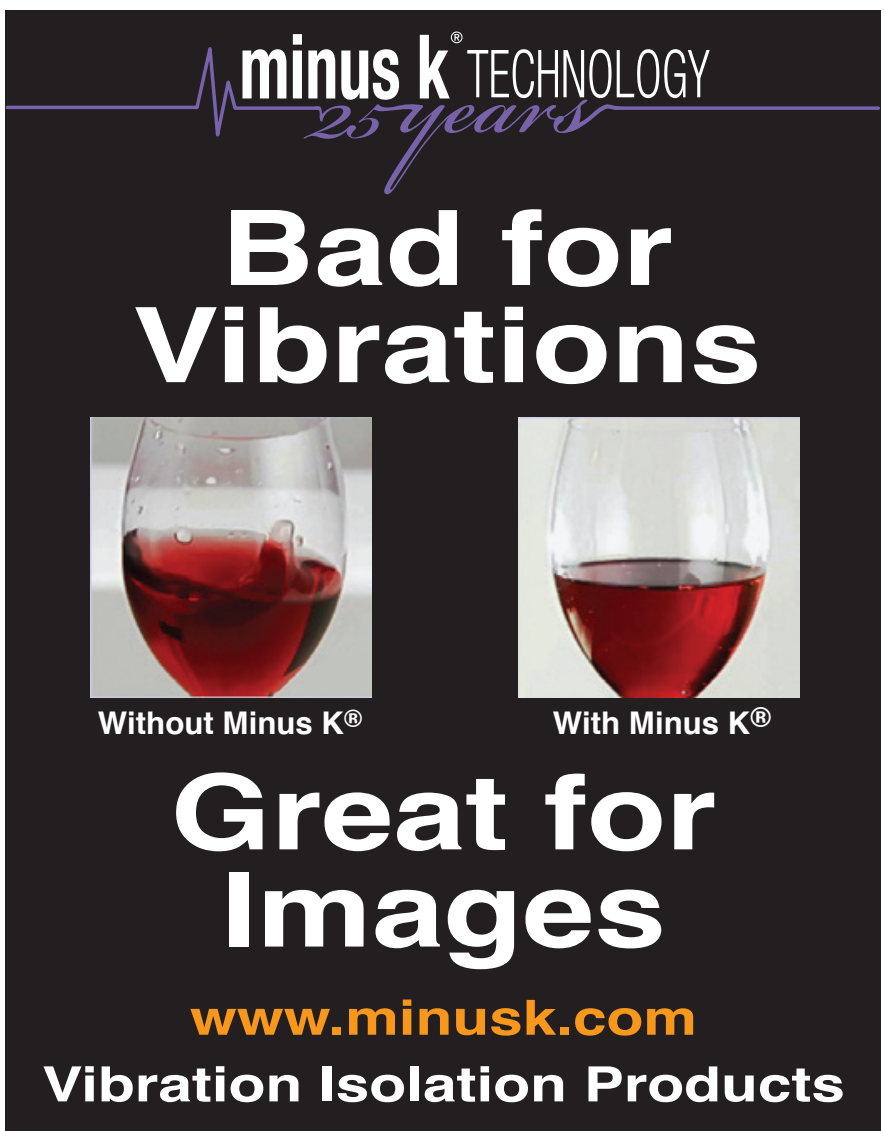

\section{Vibration Isolation Products}

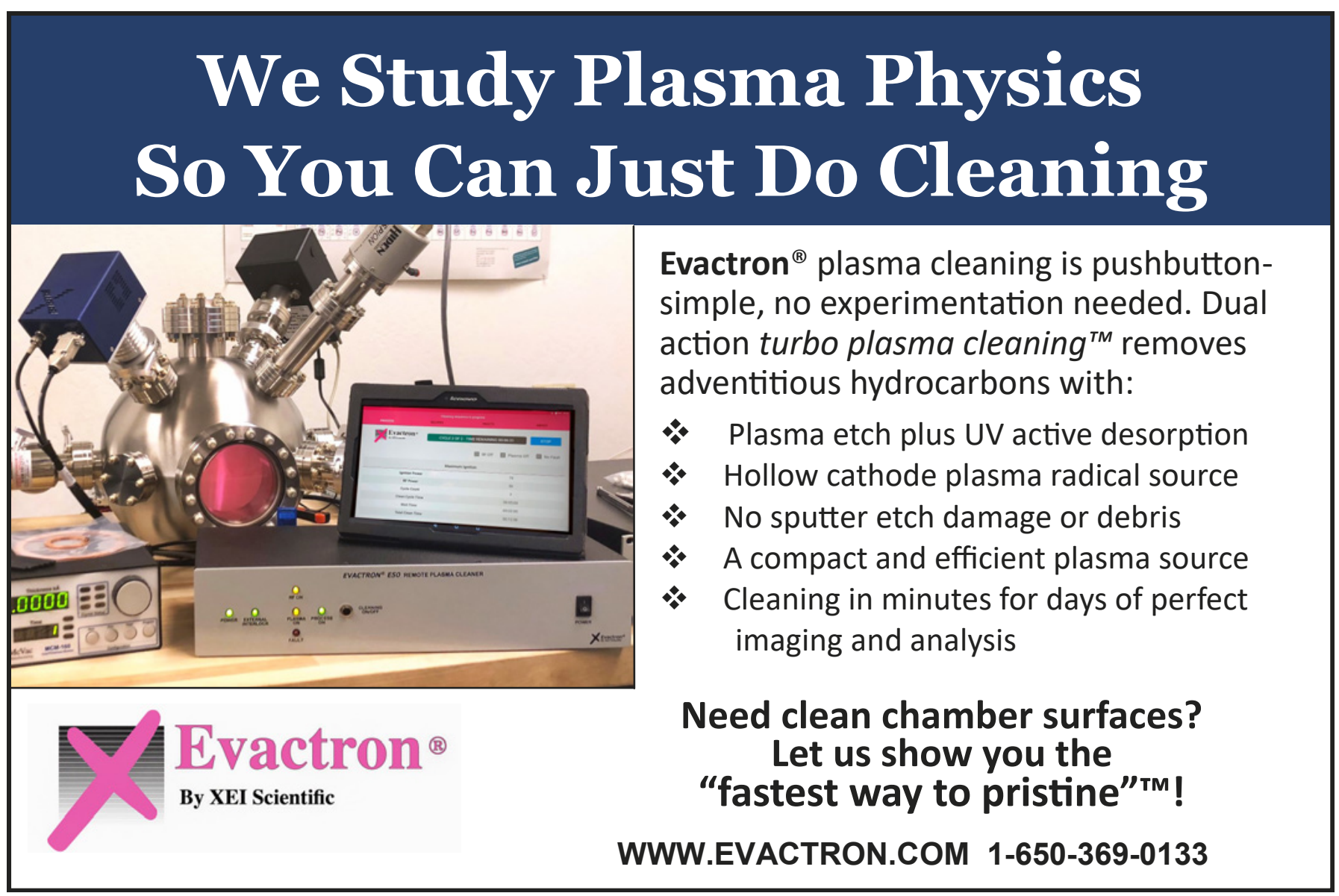


